AL IBTIDA: JURNAL PENDIDIKAN GURU MI (2020) Vol 7 (2) : 166-178

DOI: http://dx.doi.org/10.24235/al.ibtida.snj.v7i2.6314

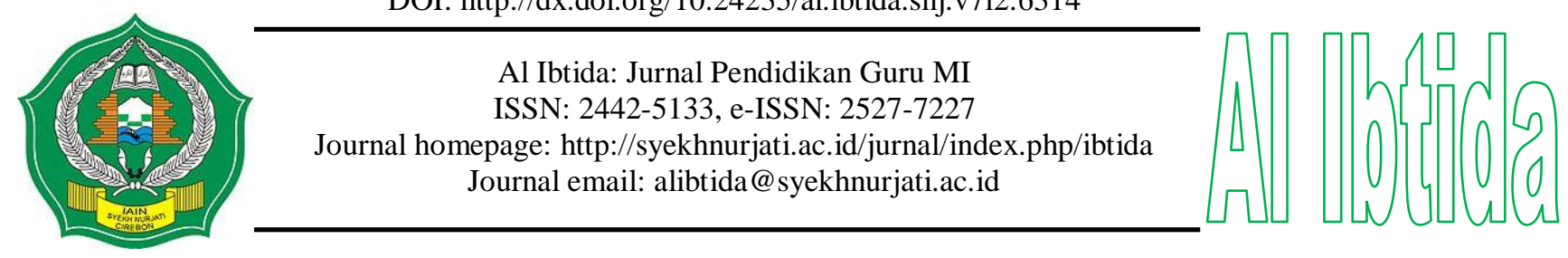

\title{
Developing Module for Two-Dimensional Course Based on Ethnomathematics for Fourth Grade of Elementary School Student
}

\author{
Dyah Triwahyuningtyas* \\ *Elementary School Teacher Education Study Program, Faculty of Science Education, \\ Universitas Kanjuruhan Malang, Indonesia \\ Email: dyahtriwahyu@unikama.ac.id \\ Novia Eka Mahmuda** \\ **Elementary School Teacher Education Study Program, Faculty of Science Education, \\ Universitas Kanjuruhan Malang, Indonesia \\ Email: noviaekamamhmuda97@gmail.com \\ Yulianti**** \\ ***Elementary School Teacher Education Study Program, Faculty of Science Education, \\ Universitas Kanjuruhan Malang, Indonesia \\ Email: yulianti@unikama.ac.id
}

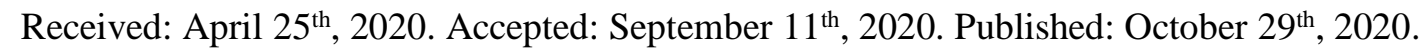

\begin{abstract}
This research was conducted due to the limitation of independent instructional media for students that is based on the curriculum as a companion to mathematics textbooks. Where the textbooks do not connect mathematics with local culture, so that students are less familiar with their culture. This research aims to develop a valid, practical, and effective module for two-dimensional course based on ethnomathematics for fourth grade students of elementary school. The model employed in this development research was 4D model proposed by Thiagarajan that consisted of four stages: Define, Design, Develop, and Disseminate. The data analysis was done by using descriptive quantitative and qualitative. The results of this development showed that the module for two-dimensional course based ethnomathematics was valid and feasible; it was stated by the average score obtained from the experts $(87.6 \%)$. Furthermore, the module developed obtained a positive response from the teacher and students; it obtained an average score of $88.5 \%$. Then, the module was effective to improve student understanding, it obtained an average score of 81.55. Therefore, the module for two-dimensional course based on ethnomathematics is valid, practical, and effective to be used in the learning process.
\end{abstract}

Keywords: two-dimensional shapes, ethnomathematics, developing module. 


\begin{abstract}
Abstrak
Penelitian ini dilatarbelakangi perlu adanya bahan ajar mandiri berupa modul siswa yang sesuai dengan kurikulum sebagai pendamping buku pelajaran matematika. Di mana buku pelajaran matematika yang digunakan kurang menghubungkan matematika dengan budaya lokal, sehingga siswa kurang mengenal budaya yang ada di daerah. Tujuan penelitian ini untuk mengembangkan modul bangun datar berbasis etnomatematika untuk siswa kelas 4 sekolah dasar yang valid, praktis dan efektif. Metode penelitian pengembangan menggunakan model 4D dari Thiagarajan yang terdiri dari empat tahap, yaitu: tahap pendefinisian (define), tahap perancangan (design), tahap pengembangan (develop), dan tahap penyebaran (disseminate). Analisis data dilakukan dengan menggunakan teknik analisis data deskriptif kualitatif dan kuantitatif. Hasil penelitian menunjukkan bahwa modul bangun datar berbasis etnomatematika dinyatakan valid oleh para ahli dengan skor rata-rata 87,6\%. Penggunaan modul mendapatkan respon yang positif dari guru dan siswa yaitu menunjukkan rata-rata $88,5 \%$. Dengan menggunakan modul tersebut, pemahaman siswa menjadi meningkat dengan nilai rata-rata mencapai 81,55. Sehingga modul bangun datar berbasis etnomatematika praktis dan efektif dalam pembelajaran matematika.
\end{abstract}

Kata kunci: bangun datar, etnomatematika, pengembangan modul.

\title{
INTRODUCTION
}

Learning Mathematics does not only talk about how to acquire a formula, master certain problem-solving process, and/or understand certain definition, argument, and proof. It also deals with how to develop a mathematical thinking pattern (Nunez, 2015; Waziri, Saidu, \& Musa, 2010). Mathematics learning within the 2013 Curriculum is designed to improve student's creativity, innovative thinking, and productivity. Hence, students could stimulate their creativity inconcerning with the learning environment. Consequently, students could apply their cognitive, attitude, and psychomotor domains to a greater degree (Ahdianto, 2016; Imswatama \& Lukman, 2018). In the implementation of the 2013 Curriculum, it should employ an instructional media that is appropriate to student's characteristics such as attitude, cognitive, and psychomotor domains. The three domains are simultaneously connecting with the topics studied by the students. An instructional media is developed to facilitate teacher in delivering lesson and allow students in understanding it during the learning process (Saputra \& Fiazah, 2017). In addition, an instructional media should be designed by integrating the local potency of certain region (Suratmi, Laihat, \& Santri, 2018). Consequently, the developed instructional media becomes more attractive and interactive for students and it is able to promote better understanding of learning topics.

According to the observation results, teacher mostly used textbooks and student's worksheet containing lesson topics and exercises as the primary instructional media for Mathematics lesson. Unfortunately, the employed textbooks and student's worksheet presented unattractive lesson information. Learning process did not maximally in developing 
student understanding about Mathematics. In addition, what are presented in the textbooks and student's worksheet did not represent a social and cultural aspects around students. Therefore, students considered Mathematics as an unattractive lesson to be studied. In resolving the explained issues, thus, it is important to develop a supplementary instructional media in the form of module for student.

Module is a learning material unit which is arranged in a linear sequence by using an understandable language and is adjusted to student's characteristics (Handayani, 2018; Izzati $\&$ Fatikhah, 2015), therefore, it promotes better lesson understanding, learning independence, and improves learning students motivation (Kuswono \& Khaeroni, 2017). Furthermore, a module employed in the learning process promotes an alteration of student's way of thinking, even beliefs in a rational way, and ables to enforce a problem-solving ability for real-life context (Mahfar, Aslan, Noah, Ahmad, \& Jaafar, 2014) through learning activities and evaluations to measure student's understanding (DeWitt \& Siraj, 2010). Thus, through the use of module, students are able to understand the lesson and perform a mathematical problemsolving.

Geometry is a a branch of Mathematics concerned with shapes, lines, points, spaces and also deals with how to connect certain form and pattern such as angle, length, width, and volume (Biswas, Dumitrescu, \& McKay, 2020; Yang \& Wang, 2017). Geometry lesson aims in studying a property of shapes and spaces, drawing a various forms of shape (Nur'aini, Harahap, Badruzzaman, \& Darmawan, 2017) and it aims in enforcing student's critical thinking as well as responsibility in completing the assignments (Verner, Massarwe, \& Bshouty, 2019; Wares \& Elstak, 2018). Geometry lesson is taught in every educational degree, starting from elementary to senior high school. It usually correlates with the surrounding phenomena and environment of students, therefore, the students are able to solve the problems related to geometry such as square, rectangle, and triangle (Safrina, Ikhsan, \& Ahmad, 2018; Yi, Flores, \& Wang, 2020). In learning geometry, students are invited to learn and understand the surrounding stuffs that could be related with the geometry concept and it could also be correlated with the cultural values.

Culture constitutes an action, behavior, system, idea, human work, language, symbol, or even a myth within certain community and it plays a role as a cultural heritage within certain community (Abdullah, 2017; Supiyati, Hanum, \& Jailani, 2019). Culture is closely related to the community identity such as how to dress, how to behave, how to farm, create, and how to solve problem using mathematical concept in the real-live situation (Muhtadi, Sukirwan, Warsito, \& Prahmana, 2017). In obtaining a better mathematical understanding, it 
is important to connect it with the cultural values attached to students. This is commonly called as ethnomathematics (Aikpitanyi, 2017).

Ethnomathematics constitutes a concept and practice related to the common mathematical activities in school such as calculating, measuring, and weighing that are connected with historical concept. This approach promotes that different thinking patterns could also generate a mathematical form (Hardiarti, 2017; Kalinec-Craig, Prasad, \& Luna, 2019; Zayyadi, 2017). In addition, Ethnomathematics allows students to learn about the development of certain cultural community which becomes a fundamental element by understanding, interpreting, and connecting the cultural reality (Cimen, 2014; Owens, 2014). In addition, it allows students to understand human condition related to cultural aspects in a natural way (Davis, 2016), thus students could have a critical thinking systematically (Imswatama \& Lukman, 2018). Mathematical concept within a cultural frame around the community or within a historical heritage should be preserved. Thus, both Mathematics and Culture could be connected.

Several previous studies developed an instructional media for geometry lesson. One of them was an instructional media containing a two-dimensional lesson by employing effective problem-solving exercises to improve the students ability in solving mathematical problem (Annisah, 2018). Then, one previous study developed an instructional media in the form of module by using CTL approach to facilitate students in acquiring a Mathematics concept independently (Yuniasih \& Wahyuningtyas, 2019). Mathematics could be integrated with a cultural aspect. In addition, the emphasize on the cultural aspects could be enforced as one approach to introduce a culture to students (Sunzuma \& Maharaj, 2020) through informal learning method to develop the relationship between cultural aspects and mathematical ability (Prieto, Claeys, \& González, 2015). An innovation based on the cultural aspects could be taken as a strategy to reduce the problems within conventional learning (Aikenhead, 2017). Previous studies also provided an example about a cultural aspect such as a traditional housing from the tribes around Indonesia, particularly a traditional housing of Papuan such as Rumah Kaki Seribu. It could take as one example for explaining a triangle concept (Haryanto, Nusantara, Subanji, \& Rahardjo, 2016). Furthermore, this could also enable students to explore cultural elements within the architecture of traditional building, for example a Sasak traditional architecture in Lombok Island such as a housing called Bale, worshipping building called Masjid, rice barn called Sambi (Supiyati et al., 2019). There is a need for innovation in the development of mathematics media. It is associated with other regional cultures in Indonesia. In this study, mathematics teaching topic will be developed in the form of 
independent modules for students based on local culture, especially historical relics such as temples and batik in Malang (ethnomathematics).

\section{METHODS}

This research was a development research on 4D development model. It consist of Define, Design, Develop, and Disseminate stages proposed by Thiagarajan (Thiagarajan, Semmel, \& Semmel, 1974). The researchers decided to choose the 4D model since it has detailed and structured stages and it allowed the researcher to conduct a straight forward development of product and its instrument due to the time limitation.

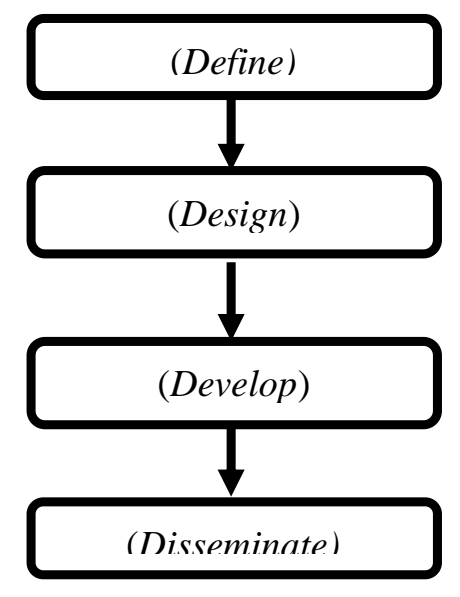

Figure 1. 4D Development Model

The first stage was defining. In this stage, the researchers conducted an observation and interview, analysis of initial-final product development. The analysis involved all the related stakeholders such as students and lesson material by identifying a basic competence, sub-competence, indicators, and the learning objectives. Then, it was followed by the stage of design. In this stage, the researchers decided what instructional media that was aimed to be developed including format and the initial design of product. After that, the researchers continued with the development stage. In this stage, the researchers administered a validity of the assessment. The researchers used questionnaire validity and appointed content in instructional media experts. The researchers also distributed questionnaire responses to the teacher and students to assess the practical activity. In measuring the effectiveness of product and the students understanding about the lesson, the researchers administered a posttest. Last but not least, the stage of disseminating was performed by distributing the module of Ethnomathematics to the fourth grade students of elementary school.

The data obtained in this research was quantitative and qualitative. The quantitative data were in the form of score obtained during the validation process. While, the qualitative data presented in the description. It consist of a suggestion and input from the experts. The 
instrument applied were validation sheets, questionnaire response for teacher and student, and test items for student learning outcomes. The data analysis was done through descriptive qualitative and quantitative.

\section{RESULTS AND DISCUSSION}

The development of two-dimensional shapes lesson module based on Ethnomathematics for the fourth-grade of elementary school was performed according to 4-D model that consisted of four stages as follows (Thiagarajan, Semmel, \& Semmel, 1974). The stage of defining explained the analysis results about students' responses in the learning process, the learning instrument used in the classroom, the identification of student's basic competences in Mathematics subject, and the development of student's cognitive level. In terms of instructional materials, it required a supplementary instructional media that is connected with the real-life context in the form of self-contained and user-friendly media. It means that the instructional media should be designed systematically and should employ an understandable language (Izzati \& Fatikhah, 2015). Based on the results, thus it is important to develop independent instructional media for students.

The following stage was designing. In this stage, the researchers designed the module starting from the cover, guidelines, main lessons that were completed with additional knowledge or information, student's exercises and evaluation tests along with the discussion and assessment. The following table presents the detailed design of the module for twodimensional course based on ethnomathematics.

Table 1. The Module for Two-dimensional Course based on Ethnomathematics

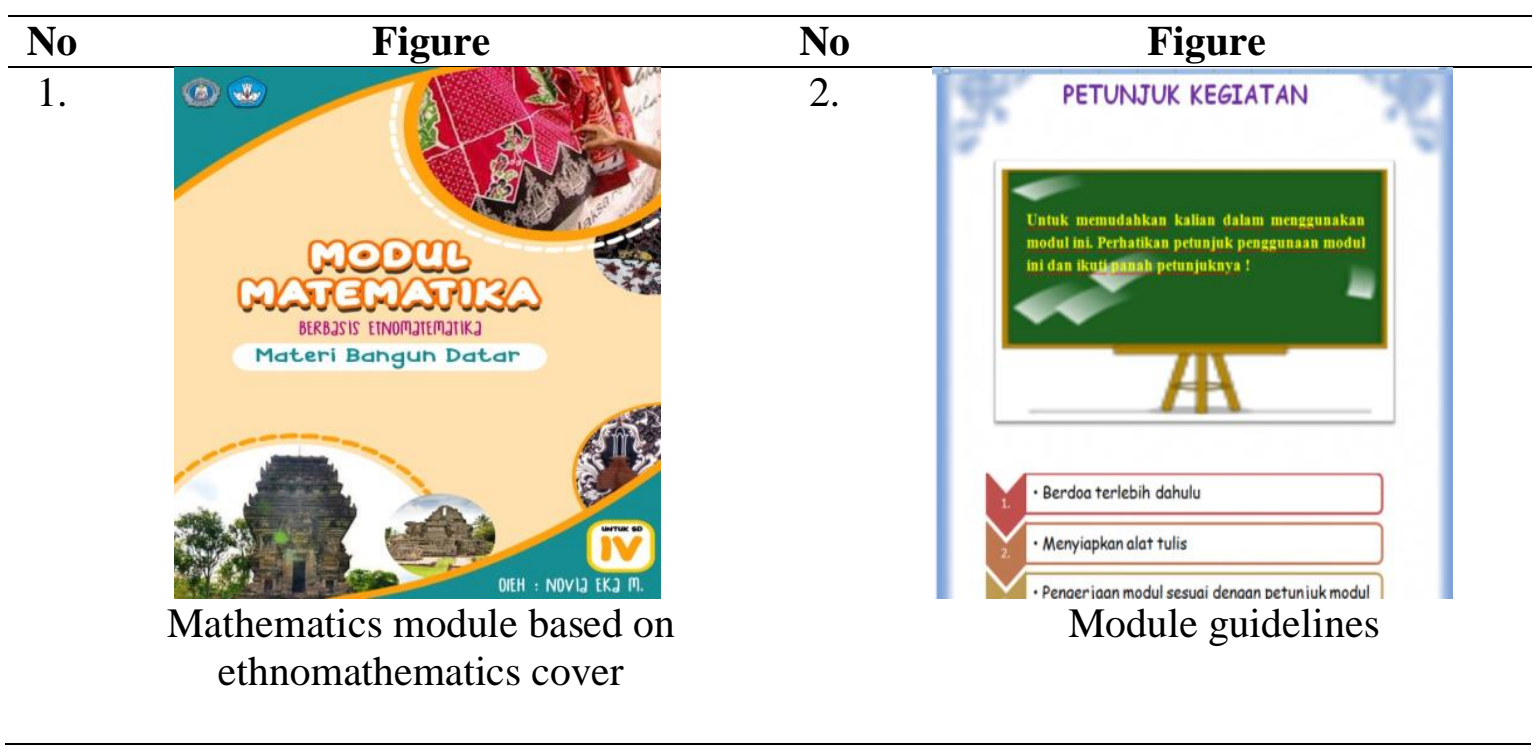


3.

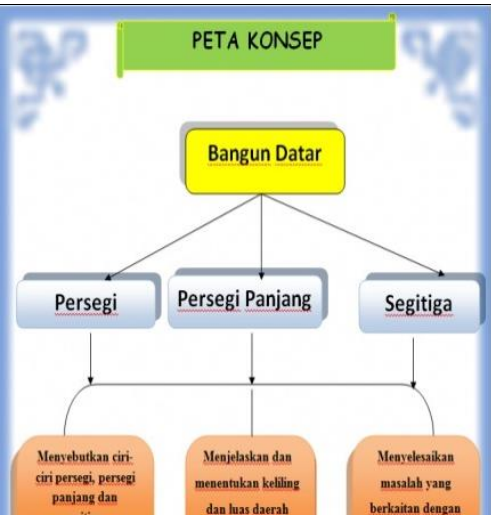

Conceptual map of mathematics module for two-dimensional course

5.

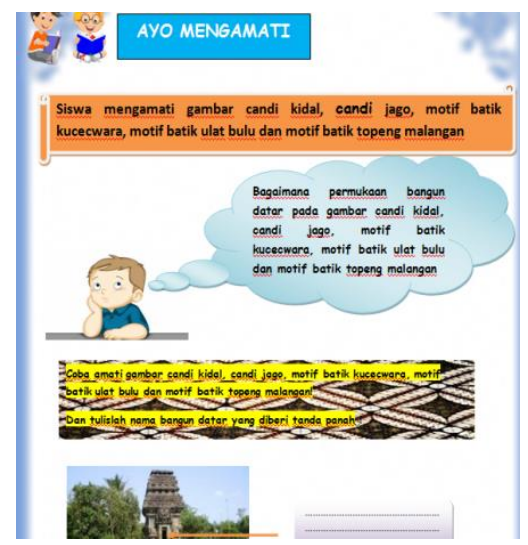

Students observing figure and determining the two-dimensional shapes formed

7.

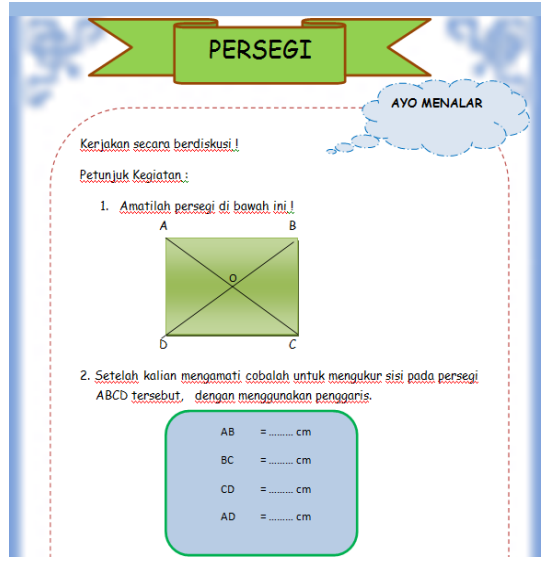

Square
4.

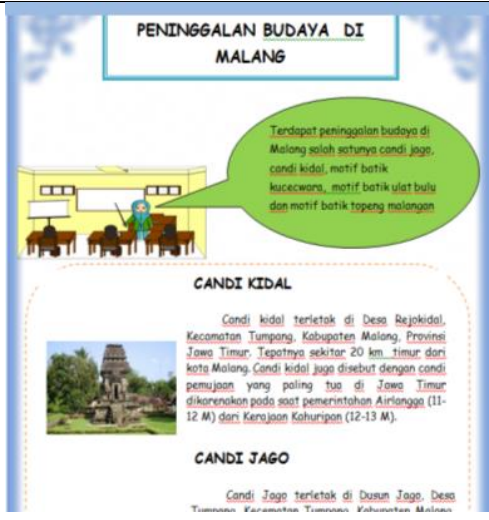

Module introduction part describing the cultural heritage in Malang

6.

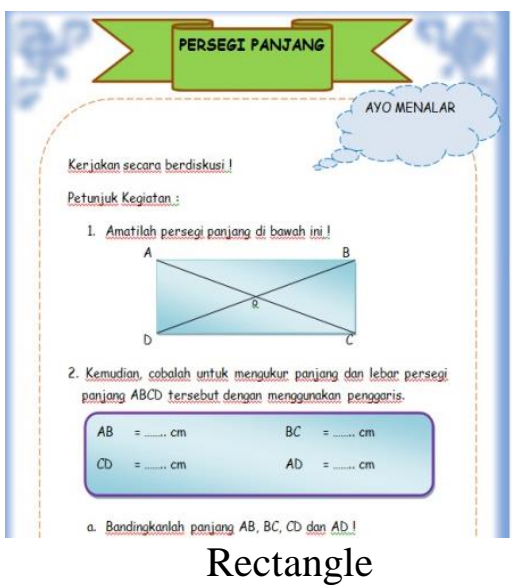

8.

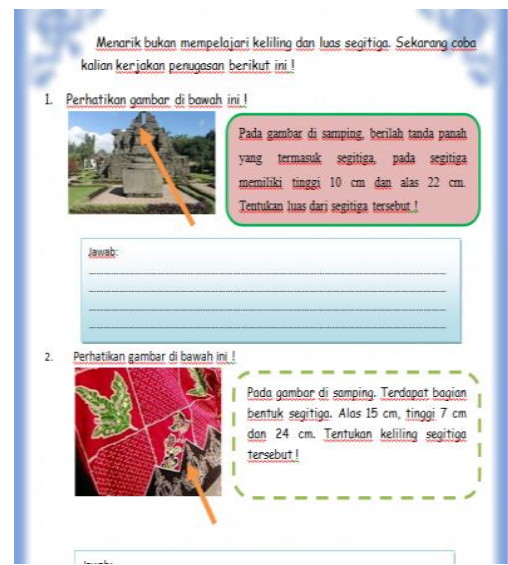

Exercise based on ethnomathematics 

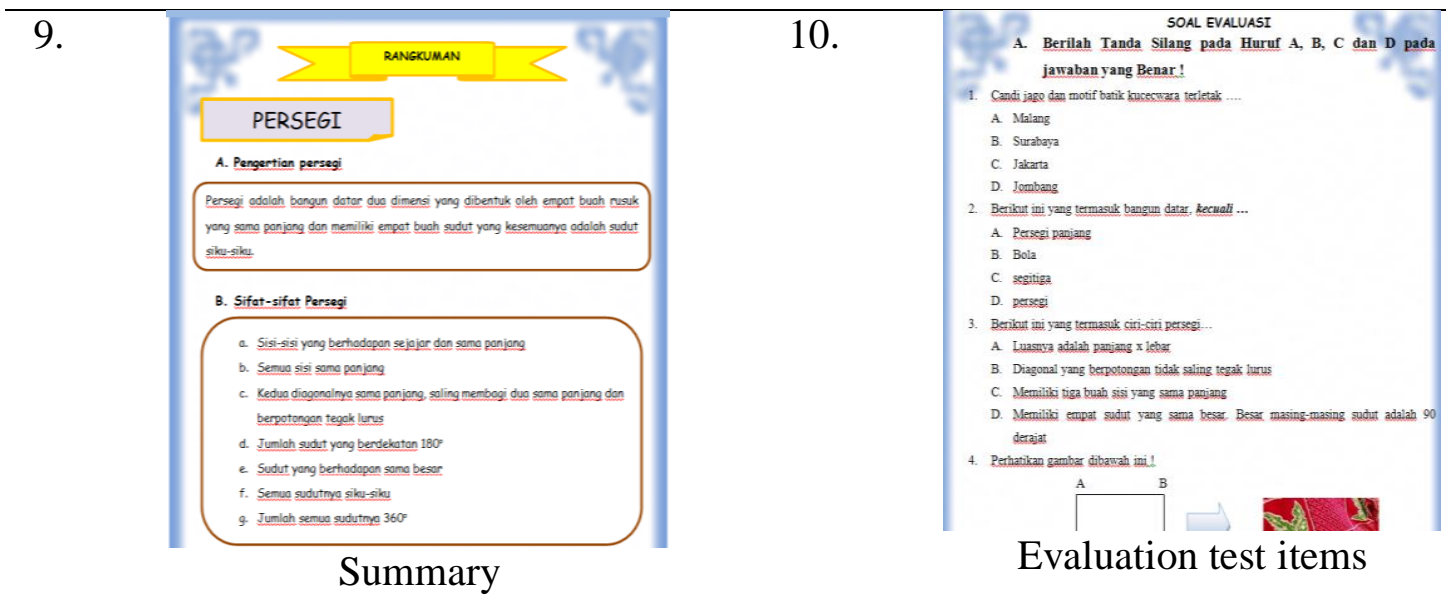

The content of module for two-dimensional course based on ethnomathematics consisted of: determining the shapes properties, the areas and circumference concept of square, rectangle, and triangle (Reasoning Activity). The following activity is twodimensional exercise items related to the cultural heritage of Malang (Jago Temple, Kidal Temple, Kucecwara Batik Patterns, Caterpillar-patterned Batik and Malangese Mask Batik) (Let's Try and Do It). In this ethnomathematics module, both culture and mathematics are correlated each other (Balamurugan, 2015). Some previous studies also presented an ethnomathematics concept, for instance: presenting a Baduy Tribe culture (Arisetyawan, Suryadi, Herman, \& Rahmat, 2014), Sasak architecture in Lombok (Supiyati et al., 2019), Sundanese language in Mathematics lesson (Muhtadi et al., 2017), and traditional housing of Papuan (Haryanto, Nusantara, Subanji, \& Rahardjo, 2016). Therefore, the correlation of Mathematics with culture around the students could enforce the critical thinking (Imswatama \& Lukman, 2018; Zayyadi, 2017).

The development stage focused on the validation product. The validation was performed by the appointed experts using validation sheets instrument. The data obtained from the validation sheets were a score that determined the degree of product validity. The results of validation score and the category are presented in the following Table 2.

Table 2. Media Expert Validation Results

\begin{tabular}{clcc}
\hline No. & Aspects Assessed & Validation Results & Category \\
\hline 1. & Graphic design & $85 \%$ & Very Valid \\
2. & Presentation & $91,66 \%$ & Very Valid \\
3. & Language & $93,75 \%$ & Very Valid \\
\hline & Average & $90,13 \%$ & Very Valid \\
\hline
\end{tabular}

According to the results, the aspects assessed to determine the validity of module were: graphic design, presentation, and language aspects. Based on the results presented above, the average validity percentage obtained was $90.13 \%$. This number is considered as 
very valid. Then, the second validation was performed by content experts. It aimed at validating the content composed in the module for two-dimensional course based on ethnomathematics. The validation score was obtained through validation sheet instrument. Thus, it obtained a data in the form of percentage that determine the validation level of the content in the module. The results are presented in the Table 3.

Table 3. Content Expert Validation Results

\begin{tabular}{clcc}
\hline No. & Aspects Assessed & Validation Results & Category \\
\hline 1. & Content & $87,5 \%$ & Very Valid \\
2. & Presentation & $93,1 \%$ & Very Valid \\
3. & Language & $75 \%$ & Valid \\
\hline & Average & $85,2 \%$ & Very Valid \\
\hline
\end{tabular}

According to the results in Table 3, the validity results of the module from the three assessed aspects (content, presentation, and language aspects) obtained a percentage of $85.2 \%$ and it is considered as very valid. Therefore, based on the overall validation from the two experts, it obtained an average percentage of $87.6 \%$ and it is considered as very valid. Then, the researchers distributed a questionnaire to 20 students and the classroom teachers who have understood the characteristics of the students. The results of responses from the students and teachers are presented in Table 4 and 5.

Table 4. The Results of Students' Responses

\begin{tabular}{clll}
\hline No. & Aspects assessed & Validity & Interpretation \\
\hline 1. & Presentation & $89,28 \%$ & Very Effective \\
2. & Content & $88,88 \%$ & Very Effective \\
3. & Language & $87,5 \%$ & Very Effective \\
\hline & Average & $88,55 \%$ & Very Effective \\
\hline
\end{tabular}

Table 5. The Results of Teachers' Responses

\begin{tabular}{clcl}
\hline No. & Aspects assessed & Validity & Interpretation \\
\hline 1. & Attractiveness & $87,18 \%$ & Very Effective \\
2. & Content & $89,37 \%$ & Very Effective \\
3. & Language & $91,87 \%$ & Very Effective \\
\hline & Average & $89,47 \%$ & Very Effective \\
\hline
\end{tabular}

Based on the results of responses given by the students and teachers presented in Table 4 and 5, it indicated the practicality of the developed module. The module developed obtained an average percentage of $88.55 \%$ from the students. It further means that the module is very effective. Then, it obtained an average score of $89.47 \%$ from the teachers. It means that the module is very effective. Therefore, it could be concluded that the module for twodimensional course is feasible to students. Furthermore, through the application of this module, teacher will be more motivated to implement and deliver ethnomathematics concept 
within geometry lesson (Verner et al., 2019). In addition, students also provided positive responses during the ethnomathematics lesson (Astuti \& Purwoko, 2017).

For measuring the effectiveness the researchers administered a test on the learning outcomes. The minimum criteria of the test is when the students obtain a score of $\geq 60$. This score indicated an understanding of lesson acquired by the students. Based on the test results, it obtained an average score of 81.55. This number was obtained from the whole students score on the learning outcomes test and was analyzed through a quantitative analysis by determining the mean of the test score. The test was administered to 20 fourth-grade students. It means that the module is very effective to improve the students's understanding. Furthermore, the understanding acquired by the students has been consistent with the minimal standard of learning mastery and the indicators could be achieved by the students. Therefore, it can be concluded that the students achieved the standard set in the learning activities and they acquired sufficient understanding. This further confirm that the approach developed in the module could improve the students academic achievement (Abiam, Abonyi, Ugama, \& Okafor, 2016) and it is able to enforce student's mathematical problem-solving ability (Widada, Herawaty, Anggoro, Yudha, \& Hayati, 2019).

Based on criteria of the module for two-dimensional course that have been achieved, the developed module for two-dimensional course based on ethnomathematics for fourth grade students of elementary school has been satisfied the three criteria of module feasibility; valid, practical, and effective. Thus, the module developed could be applied in the learning process of elementary school. This module was integrated with the cultural heritage of Malang. Furthermore, by learning through this module student could understand and solve mathematical problems related to two-dimensional shapes as well as understanding the local culture of Malang.

\section{CONCLUSION}

Based on the results and discussion above, the development of module for twodimensional course based on ethnomathematics for fourth grade students of elementary school was considered feasible and valid to be applied. This conclusion was made based on the validity score obtained from the instructional media expert (obtained an average score of 90.13\%) and content expert (obtained an average score of 85.2\%). The scores indicated that the media is very valid to be applied. Furthermore, the practicality was tested by using questionnaire to the teacher and students. The average responses score from the teacher obtained an average score of $88.55 \%$ while the average responses score from the students obtained an average score of $89.47 \%$. The score obtained showed that the module is practical. 
After that, it evaluated the effectiveness of the module by administering an evaluation test to the students. Most students obtained a score of $\geq 60$ or the average evaluation score was $81.55 \%$. Thus, it can be concluded that the module based on ethnomathematics is feasible to be used. Then, through this research, it is expected that the development of module for twodimensional course could improve the teaching quality of Mathematics teacher in the classroom. The development of module could provide an information for students regarding to the Mathematics. It is related to the surrounding culture of students

\section{REFERENCES}

Abdullah, A. S. (2017). Ethnomathematics in perspective of sundanese culture. Journal on Mathematics Education, 8(1), 1-16. https://doi.org/10.22342/jme.8.1.3877.1-15

Abiam, P., Abonyi, O., Ugama, J., \& Okafor, G. (2016). Effects of Ethnomathematics-based Instructional Approach on Primary School Pupils' Achievement in Geometry. Journal of Scientific Research and Reports, 9(2), 1-15. https://doi.org/10.9734/jsrr/2016/19079

Ahdianto, E. (2016). Pengembangan Modul Pembelajaran Geometri Bangun Datar Berbasis Teori Van Hiele untuk Siswa Kelas VI Sekolah Dasar. Jurnal Pendidikan Dasar Nusantara, 1(2), 37-48.

Aikenhead, G. S. (2017). Enhancing School Mathematics Culturally: A Path of Reconciliation. Canadian Journal of Science, Mathematics and Technology Education, 17(2), 73-140. https://doi.org/10.1080/14926156.2017.1308043

Aikpitanyi, L. A. L. (2017). Mathematics Teachers' Use of Ethnomathematics Approach in Mathematics Teaching in Edo State. Journal of Education and Practice, 8(4), 34-38.

Annisah, S. (2018). Pengembangan Bahan Ajar Matematika Materi Geometri untuk Meningkatkan Kemampuan Pemecahan Masalah Mahasiswa PGMI IAIN Metro. Al Ibtida: Jurnal Pendidikan Guru MI, 5(1), 39.

Arisetyawan, A., Suryadi, D., Herman, T., \& Rahmat, C. (2014). Study Ethnomathematics : A Lesson of Baduy Culture. International Journal of Education and Research, 2(10), 681-688.

Astuti, E. P., \& Purwoko, R. Y. (2017). Integrating Ethnomathematics in Mathematical Learning Design for Elementary Schools. 4th ICRIEMS Proceedings Published by The Faculty Of Mathematics And Natural Sciences, 192-197.

Balamurugan, M. (2015). Etnomathematics; An Approach For Learning Mathematics From Multikultural Perspective. International Journal Of Modern Research And Reviews, 3(6), 716-720.

Biswas, I., Dumitrescu, S., \& McKay, B. (2020). Logarithmic Cartan geometry on complex manifolds. Journal of Geometry and Physics, 148, 103542. https://doi.org/10.1016/j.geomphys.2019.103542

Cimen, O. A. (2014). Discussing Ethnomathematics: Is Mathematics Culturally Dependent? Procedia - Social and Behavioral Sciences, 152, 523-528. https://doi.org/10.1016/j.sbspro.2014.09.215

Davis, Z. (2016). Using a cognitive-scientific inflected anthropological approach to researching the teaching and learning of elementary school mathematics: An instance 
of the use of aggregates. African Journal of Research in Mathematics, Science and Technology Education, 20(3), 289-298.

DeWitt, D., \& Siraj, S. (2010). Design and development of a collaborative mlearning module for secondary school science in Malaysia: Addressing learners' needs of the use and perceptions of technology. Procedia - Social and Behavioral Sciences, 2(2), 471-475. https://doi.org/10.1016/j.sbspro.2010.03.046

Handayani, M. (2018). Developing thematic-integrative learning module with problem-based learning model for elementary school students. Jurnal Prima Edukasia, 6(2), 166-176. https://doi.org/10.21831/jpe.v6i2.14288

Hardiarti, S. (2017). Etnomatematika: Aplikasi Bangun Datar Segiempat Pada Candi Muaro Jambi. Aksioma, 8(2), 99. https://doi.org/10.26877/aks.v8i2.1707

Haryanto; Nusantara, Toto; Subanji; Rahardjo, S. (2016). Etnomatematika Arfak: Numerasi Masyarakat Arfak. Dipublikasikan Di Proseding Seminar Pendidikan Matematika Pasca Sarjana, (July 2018).

Imswatama, A., \& Lukman, H. S. (2018). The Effectiveness of Mathematics Teaching Material Based on Ethnomathematics. In International Journal of Trends in Mathematics Education Research (Vol. 1). https://doi.org/10.33122/ijtmer.v1i1.11

Izzati, N., \& Fatikhah, I. (2015). Pengembangan Modul Pembelajaran Matematika Bermuatan Emotion Quotient Pada Pokok Bahasan Himpunan. Eduma: Mathematics Education Learning and Teaching, 4(2). https://doi.org/10.24235/eduma.v4i2.29

Kalinec-Craig, C., Prasad, P. V., \& Luna, C. (2019). Geometric transformations and Talavera tiles: a culturally responsive approach to teacher professional development and mathematics teaching. Journal of Mathematics and the Arts, 13(1-2), 72-90. https://doi.org/10.1080/17513472.2018.1504491

Kuswono, K., \& Khaeroni, C. (2017). Pengembangan Modul Sejarah Pergerakan Indonesia Terintegrasi Nilai Karakter Religius. Historia, 5(1), 31. https://doi.org/10.24127/hj.v5i1.730

Mahfar, M., Aslan, A. S., Noah, S. M., Ahmad, J., \& Jaafar, W. M. W. (2014). Effects of Rational Emotive Education Module on Irrational Beliefs and Stress among Fully Residential School Students in Malaysia. Procedia - Social and Behavioral Sciences, 114, 239-243. https://doi.org/10.1016/j.sbspro.2013.12.692

Muhtadi, D., Sukirwan, Warsito, \& Prahmana, R. C. I. (2017). Sundanese ethnomathematics: Mathematical activities in estimating, measuring, and making patterns. Journal on Mathematics Education, 8(2), 185-198. https://doi.org/10.22342/jme.8.2.4055.185198

Nunez, I. (2015). Philosophical underlabouring for mathematics education. Journal of Critical Realism, 14(2), 181-204. https://doi.org/10.1179/1476743015Z.00000000060

Nur'aini, I. L., Harahap, E., Badruzzaman, F. H., \& Darmawan, D. (2017). Pembelajaran Matematika Geometri Secara Realistis Dengan GeoGebra. Matematika, 16(2), 1-6. https://doi.org/10.29313/jmtm.v16i2.3900

Owens, K. (2014). Diversifying Our Perspectives on Mathematics About Space and Geometry: an Ecocultural Approach. International Journal of Science and Mathematics Education, 12(4), 941-974. https://doi.org/10.1007/s10763-013-9441-9

Prieto, L., Claeys, L., \& González, E. L. (2015). Transnational Alliances: La Clase MágicaNepohualtzitzin Ethnomathematics Club. Journal of Latinos and Education, 14(2), 
125-134. https://doi.org/10.1080/15348431.2015.1011470

Safrina, K; Ikhsan, M; Ahmad, A. (2018). Peningkatan Kemampuan Pemecahan Masalah Geometri melalui Pembelajaran Kooperatif Berbasis Teori Van Hiele. Jurnal Didaktik Matematika, 6(2), 52-57. https://doi.org/10.24815/jdm.v1i1.1238

Saputra, H J; Fiazah, N. I. (2017). Pengembangan Bahan Ajar Untuk Menumbuhkan Nilai Karakter Peduli Lingkungan Pada Siswa Kelas Iv Sekolah Dasar. Profesi Pendidikan Dasar, 4(1), 62-74. https://doi.org/10.23917/ppd.v1i1.3956

Sunzuma, G., \& Maharaj, A. (2020). International Journal of Mathematical Education in Inservice mathematics teachers' knowledge and awareness of ethnomathematics approaches. International Journal of Mathematical Education in Science and Technology, O(0), 1-16. https://doi.org/10.1080/0020739X.2020.1736351

Supiyati, S., Hanum, F., \& Jailani. (2019). Ethnomathematics in sasaknese architecture. Journal on Mathematics Education, 10(1), 47-57. https://doi.org/10.22342/jme.10.1.5383.47-58

Suratmi, S., Laihat, L., \& Santri, D. J. (2018). Development of Teaching Materials Based on Local Excellences of South Sumatera for Science Learning in Elementary School. Jurnal Penelitian Dan Pembelajaran IPA, 4(1), 35.

Thiagarajan, S; Semmel, D S; Semmel, M. I. (1974). Instructional development for training teachers of exceptional children: A sourcebook. In Minneapolis, MN: Leadership Training Institute/Special Education, Unicersity of Minnesota. https://doi.org/10.1016/0022-4405(76)90066-2

Verner, I., Massarwe, K., \& Bshouty, D. (2019). Development of competencies for teaching geometry through an ethnomathematical approach. Journal of Mathematical Behavior, 56(May 2017), 100708. https://doi.org/10.1016/j.jmathb.2019.05.002

Wares, A., \& Elstak, I. (2018). Constructive struggle in geometry classrooms. International Journal of Mathematical Education in Science and Technology, 5211.

Waziri, M. Y., Saidu, I., \& Musa, H. (2010). A mathematical approach on solving Hausa Puzzles in Northern Nigeria. Procedia - Social and Behavioral Sciences, 8(5), 694 699. https://doi.org/10.1016/j.sbspro.2010.12.096

Widada, W., Herawaty, D., Anggoro, A. F. D., Yudha, A., \& Hayati, M. K. (2019). Ethnomathematics and Outdoor Learning to Improve Problem Solving Ability. Atlantis Press 1st International Conference on Educational Sciences and Teacher Profession, 295, 13-16. https://doi.org/10.2991/icetep-18.2019.4

Yang, D.-C., \& Wang, T.-L. (2017). A Comparative Study of Geometry in Elementary School Mathematics Textbooks from Five Countries. European Journal of STEM Education, 1(3), 1-10. https://doi.org/10.20897/lectito.201658

Yi, M., Flores, R., \& Wang, J. (2020). Examining the influence of van Hiele theory-based instructional activities on elementary preservice teachers' geometry knowledge for teaching 2-D shapes. Teaching and Teacher Education, 91, 103038.

Yuniasih, Nury; Wahyuningtyas, D. T. (2019). Geometry Module with CTL Approach for Elementary School Learning. Advances in Social Science, Education and Humanities Research, Volume 287, 1st International Conference on Education and Social Science, 287(Icesre 2018), 241-243. https://doi.org/10.2991/icesre-18.2019.52

Zayyadi, M. (2017). Eksplorasi Etnomatematika Pada Batik Madura. EIgma, 2(2), 35-40. 